\title{
CORPORATE RESCUE TRANSPLANTS AND RELIGIOUS INFLUENCES IN DEVELOPING COUNTRIES
}

\author{
"The wicked borrow and do not repay, \\ but the righteous give generously ${ }^{1}$." \\ Psalm 37:21 \\ "And when they had nothing with which to repay, \\ he freely forgave them both ${ }^{2} . "$
}

Luke 7:42

\begin{abstract}
Legal transplanting entails the adoption in one country of (part of) the law of another country. Some developing countries have changed their law of corporate insolvency, implementing legal institutions such as corporate rescue procedures. Comparative law scholars are divided on whether legal transplantation is possible. According to Alan Watson, legal transplantation is easy, whereas Pierre Legrand is of the opinion that it is impossible. Otto Kahn-Freund adopts a more nuanced stance. All three however agree that culture has an influence on the success of legal transplants. Religion, as a component of culture, makes it more difficult to transplant certain legal institutions. This does
\end{abstract}

* LL.B. Maastricht University, The Netherlands. At the moment, the author is a LL.M. student in European law at Radboud University Nijmegen, The Netherlands, and Corporate and Insolvency law at Nottingham Trent. The author is a PhD candidate at Fulda University, United Kingdom of Applied Sciences, Germany and Martin Luther University Halle-Wittenberg, Germany.

${ }^{1}$ New International Version.

2 New King James Version. 
not mean that it is impossible to adopt one corporate rescue regime in all developing countries. It does however mean that the specific religions can have an influence on the way the new law will be used.

\section{Keywords}

Legal transplants - corporate rescue - developing countries - shari'ah - Confucianism

\section{INTRODUCTION}

In the past there have been numerous examples of countries adopting a law, multiple laws, or even entire law systems which originated in other countries $^{3}$. This phenomenon is called legal transplants ${ }^{4}$. There can be many reasons to adopt foreign law, ranging from being colonized, and thus having no other choice but to comply, to the desire to strengthen a country's economy ${ }^{5}$. The latter often applies to developing countries, however the bargaining power of international financial organizations such as the World Bank and the International Monetary Fund does also play a huge role. If a country is in financial difficulty and requests financial assistance from these institutions, they can provide loans on the condition of adoption of certain laws ${ }^{6}$. It will be shown below that culture has an effect on the application of these newly adopted laws. Religion is an important aspect of culture, so it is interesting to see how this can affect the working of imported law.

${ }^{3}$ See e.g. C. Wang, Legal Transplantation and Legal Development in Transitional China in H. Cissé and others (eds), The World Bank Legal Review: Volume 4: Legal Innovation and Empowerment for Development, Washington DC: World Bank, 2013, p. 162-163.

${ }^{4}$ A. Watson, Legal Transplants: An Approach to Comparative Law, 2nd edn, Athens (Georgia): The University of Georgia Press, 1993, p. 21.

${ }^{5}$ See e.g. G. Mousourakis, Transplanting Legal Models across Culturally Diverse Societies: A Comparative Law Perspective, "Osaka University Law Review" 2010, vol. 57, p. 91-92.

${ }^{6}$ See e.g. J. Gillespie, Transplanted Company Law: An Ideological and Cultural Analysis of Market-Entry in Vietnam, "The International and Comparative Law Quarterly" 2002, vol. 51, p. 643; T. Halliday and B. Carruthers, The Recursivity of Law: Global Norm Making and National Lawmaking in the Globalization of Corporate Insolvency Regimes, "American Journal of Sociology" 2007, vol. 112, p. 1153-1154. 
Corporate insolvency is a field of law which has been subject to new (partly) imported laws 7 . Many of these laws can be traced back to international best practices, an important aspect of which is reorganization to save companies or businesses ${ }^{8}$. But is it always possible to import these international best practices, and especially reorganization? Is there a single model of corporate rescue regime that is suitable for adoption in all developing countries? Whether a rescue regime is suitable for adoption depends of course on many factors. It is impossible to cover all of these in one article. Therefore a choice had to be made between theories and factors. This article will focus on two things: first of all, an overview will be provided of some opinions on legal transplants. Are they possible? What is actually transplanted? What should lawmakers take into consideration when transplanting law? Next, this article will turn to the religion factor. Two religions have been chosen: Islam and Confucianism, because of their presence in different developing countries ${ }^{9}$. What are the religious ideas regarding insolvency in these developing countries and in what way can religious backgrounds have an impact on the success of legal transplants? This article will be of a theoretical nature and therefore will not contain an analysis of concrete legal provisions.

\section{LEGAL TRANSPLANTS}

Many authors have written about legal transplants, so it is impossible to cover all the literature. In the following sections three views will be discussed in depth. On the one hand there is Alan Watson, according to whom legal transplants are easy and practically always possible. The other extreme is Pierre Legrand, who is of the opinion that legal transplants are impossible. Somewhere in the middle, one can find Otto Kahn-Freund, who acknowledges the possibility of legal transplants, but warns against misuse.

7 See e.g. S. Al-Barashdi, The Possibility of Transplanting Western Bankruptcy Principles to Oman, "Asian Social Science" 2016, vol. 12, p. 59.

${ }^{8}$ Ibid. at p. 63.

${ }^{9}$ Islam in the Middle East and Confucianism in the Far East. 


\section{WATSON}

According to Watson, legal transplantation entails "the moving of a rule or a system of law from one country to another, or from one people to another"10. His research showed that legal transplanting happened quite often and that transplants were many times based on Roman law. The many occurrences led him to the conclusion that legal transplants are the primary reason for legal development ${ }^{11}$. Very importantly, transplanting law is not difficult, even though there may be some opposition to importing a new rule or law. Watson claims this is because rules do not really affect people. People just need rules and the content of these rules is of lesser importance ${ }^{12}$. It also does not really matter where these rules come from, even if this is a civilization which is much more highly developed than the adopting country. It is unnecessary even to have knowledge of the circumstances in which the law operates in the country of origin ${ }^{13}$. The only thing one really needs is the will to transplant ${ }^{14}$. These conclusions lead to a logical, though controversial, follow-up conclusion: if legal transplants are common and easy and one does not need to be aware of the rule's social context in the country of origin, then there is only a very loose relation between the law and the society in which it operates ${ }^{15}$.

Watson emphasises the importance of authority ${ }^{16}$. Law is predominantly developed by lawyers, who are a special elite group in society. For them, law is an autonomous concept (law as a separate discipline, independent from, for example, economic and social influences) and to develop or interpret law, they look for authority. Authority can be found when looking at other jurisdictions, so this is what they do. The result is that the rules they adopt have more of a connection with the foreign

\footnotetext{
${ }^{10}$ Watson, Legal Transplants, supra note 4 at p. 21.

${ }^{11}$ Ibid. at p. 95.

${ }^{12}$ Ibid. at p. 95-96.

13 A. Watson, Legal Transplants and Law Reform, 1976, 98 [in:] The Law Quarterly Review
} 79, p. 79-81; ibid at p. 99.

14 Watson, Legal Transplants and Law Reform, supra note 13 at p. 83.

${ }^{15}$ Ibid. at p. 81; Watson, Legal Transplants, supra note 4 at p. 96 and 107-108.

${ }^{16}$ Watson, Legal Transplants, supra note 4 at p. 99. 
country than with the situation of their own country. Whether the rules are the best ones for their own society is less important. This does however not prevent the adopting country from altering the rule. What it means is that if society is to have an effect on which rules are made, this needs to go through lawyers and that law is in most cases based on law that was already present somewhere ${ }^{17}$.

If one considers Watson's theory, it is unsurprising to feel a bit sceptical. Of course there is some relation between law and society. If society changes, law changes ${ }^{18}$. According to Ewald, we have to make a distinction between what he describes as Strong Watson and Weak Watson ${ }^{19}$. Both Strong and Weak Watson try to combat strong mirror theories ${ }^{20}$. There are many mirror theories, but broadly speaking they represent the idea that law mirrors society and the economic, political, and social changes that occur therein. In other words, law is formed by external factors (societal influences) and not by internal factors. Law, as such, is not an autonomous concept, it is intrinsically linked to society ${ }^{21}$. A strong mirror theory is a mirror theory which claims that law is based on only one or more external factor(s) ${ }^{22}$. Ewald states that Watson tries to prove these strong mirror theories wrong. Watson does so by showing that in the past there have been numerous examples of laws which were not based on these external factors ${ }^{23}$. He, according to Ewald, does not really mean that society never has an influence on law, but that usually the elite of lawyers' looks at law itself for change instead of at society ${ }^{24}$. Ewald also reminds us that Watson's position is not: society has no

17 A. Watson, The Evolution of Law, Baltimore: The John Hopkins University Press, 1985, p. 41-42, 71-72 and 117-119; A. Watson, The Evolution of Western Private Law, Baltimore: John Hopkins University Press, 2001, p. 261 and 263-264. See also W. Ewald, Comparative Jurisprudence (II): The Logic of Legal Transplants, “The American Journal of Comparative Law" 1995, vol. 43, p. 499.

${ }^{18}$ See e.g. L. Friedman, Some Comments on Cotterrell and Legal Transplants, [in:] D. Nelken and J. Feest (eds), Adapting Legal Cultures, Oxford: Hart Publishing, 2001, p. 93.

19 Ewald, supra note 17 at p. 491.

${ }^{20}$ Ibid. at p. 491.

${ }^{21}$ Ibid. at p. 491-492.

${ }_{22}$ Ibid. at p. 493-494.

${ }^{23}$ Ibid. at p. 496.

${ }^{24}$ Ibid. at p. 500. 
relation to law, therefore law is changed by transplants, but: because of the apparent history of transplanting, society and law do not always have a strong relation ${ }^{25}$. The Strong Watson approach is that there is no relation between law and society, because we can see the vast amount of transplants. The Weak Watson approach entails a relation between law and society, but that this link is not always the reason for the existence of specific legal rules. According to Ewald, the Weak Watson approach is what Watson really stands for ${ }^{26}$.

\section{LEGRAND}

Watson and Legrand are complete opposites. Where Watson argues that legal transplants are easy, it is Legrand's thesis that they do not exist. According to Legrand, the problem lies in what constitutes a rule. Is it only the bare words, or their meaning as well? He argues the latter ${ }^{27}$. So if one wants to transfer a rule from one society to another, it is necessary to transfer both the bare words and the meaning. The meaning of a rule however dependent upon the circumstances a society is in. Interpretation of the rule requires an interpreter and this interpreter has been raised and educated in a specific society. When interpreting a rule's bare words, the interpreter applies his cultural background. If these same bare words are present in another society, this rule's interpreter has a different cultural background and will thus interpret the words in a different way. This means that in effect there are two rules, because of the different interpretations ${ }^{28}$. So if one transfers only bare words, there is no legal transplant, for the meaning has not been transferred and as a consequence the rule has not either. Transferring the meaning as well is, however, impossible, because every interpretation is dependent upon

${ }^{25}$ Ibid. at p. 502-503.

${ }^{26}$ Ibid. at p. 501 and 509.

27 P. Legrand, The Impossibility of Legal Transplants, 1997, 4 [in:] Maastricht Journal of European and Comparative Law 111, p. 114; P. Legrand, What "Legal Transplants"?, [in:] D. Nelken and J. Feest (eds), Adapting Legal Cultures, Oxford: Hart Publishing, 2001, p. 57.

${ }^{28}$ Legrand, The Impossibility of Legal Transplants, supra note 27 at p. 114-115; Legrand, What "Legal Transplants"?, supra note 27 at p. 57-58. 
the interpreter's cultural background ${ }^{29}$. Legal transplantations of rules are therefore impossible ${ }^{30}$.

\section{KAHN-FREUND}

Where Watson and Legrand can be seen as representing the exact opposites of each other, Kahn-Freund should be placed somewhere in between them. He makes a vivid distinction between two kinds of transplants, namely transplantation of body parts and of mechanical parts. The big difference between them is that transplanted body parts may sometimes be rejected by the receiving body, while for example a screw will never be rejected by a machine. The interesting question is whether legal transplants are like body parts or mechanical parts ${ }^{31}$. According to Kahn-Freund they are neither. Dependent upon the adjustability of the transplant to the receiving society, they are somewhere in between these extremes. Kahn-Freund's goal is to find out what factors play a role regarding the place of the transplant on this scale ${ }^{32}$.

The starting point is a statement by Montesquieu, namely that laws should be made for the people to whom the law is to apply. As a result of that, it is very uncommon for laws to be appropriate to other people ${ }^{33}$. The laws of a society should mirror many things, for example wealth, religion, the inhabitant's professions, habits, form of government etc. The relation between these factors and the law is what Montesquieu called the spirit of laws ${ }^{34}$. Kahn-Freund divides these factors into geographical, political, economic, sociological, and cultural ones ${ }^{35}$. He is of the opinion that the importance of the geographical, economic, sociological, and cultural factors

${ }^{29}$ Legrand, The Impossibility of Legal Transplants, supra note 27 at p. 116-118; Legrand, What "Legal Transplants"?, supra note 27 at p. 60-61.

${ }^{30}$ Legrand, The Impossibility of Legal Transplants, supra note 27 at p. 120; Legrand, What "Legal Transplants"?, supra note 27 at p. 57 and 63.

${ }^{31}$ O. Kahn-Freund, On Uses and Misuses of Comparative Law, "The Modern Law Review" 1974, vol. 37, p. 5-6.

32 Ibid. at p. 6.

${ }_{33}$ Montesquieu, The Spirit of Laws (Thomas Nugent tr, first published in French 1748), Ontario: Batoche Books, 2001, p. 23.

${ }^{34}$ Ibid.

35 Kahn-Freund, supra note 31 at p. 7. 
has declined since the publication of Montesquieu's book and that the importance of political factors has increased. The reason for the decline of the former factors is that the living conditions of many peoples have become more uniform throughout the world. Basically, people's professions are becoming similar, cultural ideas have spread through the use of television, people's houses look similar in many places etc. And this happens not only in the developed world, but increasingly as well in the developing world ${ }^{36}$. Why have political factors increased in importance? According to Kahn-Freund there is political differentiation in the world. His examples are a sign of the times in which he was writing his article. Firstly, he refers to the political divide between communism and non-communism as well as to the difference between countries governed by a dictator and those having adopted a democracy. Secondly, one should consider the different choices countries have made between parliamentary and presidential systems and the power the executive has. Thirdly, organized groups have become much more important. There are many of these groups, representing interests ranging from labour to religion. The political power of organized groups depends on the country in question ${ }^{37}$. Because of these increased political differences between countries and the lower amount of differences based on geographical, sociological, economic, and cultural factors, the success of transplantation now depends most on the persons or institutions that have adopted the rule ${ }^{38}$. Kahn-Freund's conclusion is that it is necessary for those who want to adopt a legal transplant to familiarise themselves with the external factors that have an influence on the law in the country of origin, and especially with political factors ${ }^{39}$.

\section{REVIEW}

It is clear from the previous sections that there are many possible opinions on legal transplantation as a phenomenon. Although they represent only a small part of the existing literature, what can be learnt from Watson, Ewald's interpretation of Watson, Legrand, and Kahn-Freund?

\footnotetext{
${ }^{36} \mathrm{Ibid}$. at p. 8-10.

${ }^{37}$ Ibid. at p. $11-12$.

${ }^{38}$ Ibid. at p. 12-13.

${ }^{39}$ Ibid. at p. 27.
} 
Legrand's theory is the most straightforward. To constitute a rule, bare words need meaning and this meaning is dependent upon the interpreter's interpretation, which is determined by his cultural background. Legal transplants are not possible, because it is impossible to retain the same meaning when transferring a rule, as the new interpreter will have a different cultural background. There are in effect then two different rules.

Legrand's reasoning is very logical and he is probably right to a certain extent. It is difficult to imagine that the same bare words will have the exact same meaning in different countries. Of course this also depends on the nature of the specific words. As an example one can think of the word reason. Whether there is reason to do something can differ from culture to culture. On the other hand, in the same way as it is hard to imagine that the same bare words are interpreted in the same way in different countries, it is just as hard to imagine that they have the exact opposite meaning. There will always be some result of the transplant, albeit unlikely that the rule will have the exact same meaning. In Legrand's view, we can in such a situation no longer speak of transplants. It is thus a matter of when a legal transplant is successful ${ }^{40}$. For Legrand, this is the case if the transplanted rule is exactly the same as the original. This makes his conclusion of the impossibility of legal transplants understandable, but also unhelpful as something is definitely transferred, whether one calls it legal transplantation or not.

What can be learnt from Legrand is that transferring bare words alone is not enough. How a transplant will work in a developing country is dependent upon the meaning given to it by the interpreters. So if one seeks to be successful in that the rule will work in the exact same way as in the country of origin, it is necessary to change the cultural background of the interpreters. That is very difficult, if not impossible. The result is that if one transplants a single model of corporate rescue to multiple developing countries, the transplant will in every case look different.

Watson's theory is not very easy to understand, not in the least because of the vast amount of literature he has published and the different wording he uses. Therefore it is convenient that Ewald has

${ }^{40}$ See also D. Nelken, Towards a Sociology of Legal Adaptation, [in:] D. Nelken and J. Feest (eds), Adapting Legal Cultures, Oxford: Hart Publishing, 2001, p. 35-36. 
added structure to his argument. Basically, Watson's theory states that there is not a (strong) connection between law and society, because i) legal transplants have in the past often occurred; ii) they are the main way of changing law; iii) they are easy; and iv) law is developed by a lawyer-elite who see law as an autonomous concept. Ewald discerns Strong Watson, who says that there is no relation between law and society and Weak Watson, who states that there is a connection between law and society, but that this connection does not always explain the existence of legal rules.

It is not difficult to disagree with the statement that law and society are not related. Often if a need arises in society for legislation, the legislator acts. There is for example a huge amount of plastic waste in the world and the UK government has recently announced a consultation on a ban of plastic straws and cotton buds ${ }^{41}$. This of course does not mean that all laws reflect society, nor that the possible ban will not be a transplant. It does however show that there is some relation between law and society. This means Strong Watson can be discarded. Weak Watson however is more interesting. It is indeed telling that so many legal rules have been transplanted in the past, especially Roman ones. This does seem to point in the direction that the reason for adopting a certain rule is not always to be found in the receiving society, but in the authority of the transplanted rule. It is necessary to keep two things in mind. First of all, the fact that the situation in the receiving society is not always the reason for adopting a certain rule does not mean any rule can easily be transferred. Watson himself acknowledges this, by stating that "a foreign rule will not easily be borrowed successfully if it does not fit into the domestic political context ${ }^{42}$." Secondly, Watson's research is mostly concerned with legal transplants in Europe, so it is not clear to what extent his conclusions apply to transplanting legal rules to developing countries ${ }^{43}$. In contrast to Legrand, Watson is not concerned with the fact that legal transplants may not operate exactly as in the country of origin. He considers this a normal part of transplantation ${ }^{44}$. Regarding developing countries he observes

41 BBC News, Plastic Straw and Cotton Bud Ban Proposed, 19 April 2018, available at: http:/ / www.bbc.co.uk/news/uk-politics-43817287 [last accessed 19.4.2018].

42 Watson, Legal Transplants and Law Reform, supra note 13 at p. 81.

43 Ewald, supra note 17 at p. 503.

44 Watson, Legal Transplants, supra note 4 at p. 116. 
that it is not apparent that the transplant has failed it remains unused. The transplant may just need time, as the same applied to Roman law ${ }^{45}$.

Watson's theory shows that legal transplants are possible, very normal and that transplantation does not have to be difficult. Developing countries should not be too concerned about the external factors present in the transplant's country of origin. It is however important to have the will to adopt the new rules. Based on Watson's theory, it is tempting to say that transferring a single model for corporate rescue to all developing countries should not be very problematic. At least it provides a reason to state that this single model is not so connected to the originating country that issues arise when transplanting. The model should however be able to fit into the adopting country's society.

Kahn-Freund argues that society and law are connected. Agreeing with Montesquieu, he is of the opinion that law mirrors external geographical, economic, sociological, cultural, and political factors. However, since the time of Montesquieu the first four categories have decreased in importance and the last one has gained importance. To be able to predict the success of a legal transplant, one should have an understanding of the connection between the law and these external factors, especially political. If there is a strong connection and the same political factors do not exist in the adopting country, it will be more difficult to transplant successfully. Is Kahn-Freund right in saying that political factors have increased in importance? It is doubtful whether his arguments are still persuasive anno 2018. The communist world has almost entirely collapsed and given way to capitalism, and democracy is slowly spreading through the world. On the other hand, there are indeed many organized groups having a varying degree of influence on the legislative process. This is however not in itself enough to speak of political differentiation. If one, for example, looks at the European Union, it is hard to see truth in such a claim. It is easier to agree on the unification of the other external factors. Since Kahn-Freund wrote his article in 1974, living conditions have become even more similar than before. Next to the examples given by him, the internet has provided many people worldwide with access to information, people are travelling all over the world to work or study, and there are many more examples of unification.

${ }^{45}$ Watson, Legal Transplants and Law Reform, supra note 13 at footnote 17. 
Kahn-Freund highlights the relation between law and external factors and reiterates the importance of taking this connection into consideration when considering the possible success of future transplants. When assessing whether it is possible to adopt a single rescue model in all developing countries, it is important to look at the relation between the rescue model and the external factors of both the country of origin and the adopting country. If there is a relation between the law and the external factors in the country of origin which is not present in the adopting country, this can have a serious impact on the success of the transplant.

\section{RELIGION AND INSOLVENCY}

One common conclusion between Watson, Legrand, and Kahn-Freund is that culture has an influence on legal transplants, although the impact of this influence is contentious. According to Legrand it has an influence on how the adopted rules are interpreted. Watson acknowledges that it is more difficult for a transplant to be successful if it does not fit into the adopting country's society, and Kahn-Freund and Montesquieu state that culture is one of the factors which the law reflects, so there is a chance of failure if the culture of the adopting country and country of origin are not similar. Religion is an important part of culture and it is clear that religion can play a role in the use of insolvency proceedings ${ }^{46}$. Religion also plays a role in the political factor which Kahn-Freund sees as the most important external factor. There can for example be religious organizations which have an influence on which rules are adopted and which not ${ }^{47}$.

The following sections will look at some religious views on insolvency in Islamic law and Confucianism. The overview is by no means meant to be exhaustive. After this, a discussion will follow on what these views mean for legal transplantation to developing countries. The chosen religions are only exemplary for religions in developing countries. They

${ }^{46}$ See e.g. J. Sutherland, The Ethics of Bankruptcy: A Biblical Perspective, 1988, 7 [in:] Journal of Business Ethics 917; J. Beck and others, Regional Differences in Chapter 13 Filings: Southern Legal Culture or Religion?, "Review of Social Economy" 2014, vol. 72, p. 186.

47 See e.g. Kahn-Freund, supra note 31 at p. 15-16. 
are not chosen because there is now or will be a legal transplant in countries which are influenced by these specific religions.

\section{SHARI'AH}

It is important to observe at the beginning that Islamic law does not know a distinction between theinsolvency of natural persons and companies ${ }^{48}$. The reason is that Islamic law is unfamiliar with the concept of limited liability. Business was instead conducted through for example partnerships ${ }^{49}$.

The starting point of Islamic bankruptcy consists of two verses from the Qur' $\mathrm{an}^{50}$. Verse 2:280 states: "If the debtor is in a difficulty, grant him time till it is easy for him to repay. But if you remit it by way of charity, that is best for you if you only knew." On the other hand it is stated in Verse 5:1: "O you who believe! Fulfil (all) obligations." So there are two opposite principles: it is important for debtors to repay their debts, but creditors must give debtors who cannot repay extra time. Next to that, there is a voluntary option to release debtors of their debt ${ }^{51}$. A lot of emphasis is however put on the obligation to repay and the consequence of not paying is committing a sin, which can have grave consequences ${ }^{52}$. Compulsory discharge of debt is unknown in Islamic bankruptcy. Verse 2:280 second sentence only gives an advice: it is good to remit. If a creditor does not remit the debt, it remains in existence until the debtor dies $^{53}$.

48 A. Awad and R. Michael, Iflas and Chapter 11: Classical Islamic Law and Modern Bankruptcy, 2010, 44 [in:] The International Lawyer 975, p. 983-985; H. Ala Hamoudi, The Surprising Irrelevance of Islamic Bankruptcy, 2011, 19 [in:] American Bankruptcy Institute Legal Review 505, p. 511; J. Kilborn, Foundations of Forgiveness in Islamic Bankruptcy Law: Sources, Methodology, Diversity, 2011, footnote 6, available at: https://papers.ssrn.com/sol3/ papers.cfm?abstract_id=1908896 [last accessed 20.4.2018]; M. McMillen, An Introduction to Shari'ah Considerations in Bankruptcy and Insolvency Contexts and Islamic Finance's First Bankruptcy (East Cameron), 2012, p. 3, available at https:/ / papers.ssrn.com/sol3/papers. cfm?abstract_id=1826246 [last accessed 20.4.2018].

49 Awad and Michael, supra note 48 at p. 984.

${ }^{50}$ Translations are from A. Yusuf Ali (tr), The Meaning of The Holy Qur'an (4th rev edn by Sahib Bleher), Birmingham: Islamic Dawah Centre International, 2014.

51 Kilborn, supra note 48 at p. 3-5.

52 Awad and Michael, supra note 48 at p. 980; Kilborn, supra note 48 at p. 7-8.

${ }^{53}$ Hamoudi, supra note 48 at p. 512; Kilborn, supra note 48 at p. 20; McMillen, supra note 48 at p. 3 . 
Bankruptcy proceedings are opened by creditors ${ }^{54}$. There is no such thing as a voluntary insolvency proceeding, which is not surprising as there is no option to impose a compulsory discharge upon the creditors ${ }^{55}$. The proceedings are aimed at liquidation of the debtor's assets and this is done by a court-appointed receiver ${ }^{56}$.

An interesting question is whether reorganization proceedings are possible under Islamic law. As stated above, there is no possibility of having debts discharged, except for remission by the creditor or death of the debtor. A reorganization plan entailing changes in the amount of debt is therefore impossible unless each and every creditor agrees to the plan $^{57}$.

It has already been stated that Islamic law places a lot of emphasis on the obligation to repay one's debts and that not paying is regarded as a sin. This clearly shows a strong stigma attached to debt. This stigma is also recognisable in what happens after the appointment of the receiver. The debtor loses control of his assets to the receiver and is legally put in the same category as minors, insane people, and the incapacitated ${ }^{58}$.

Last, but certainly not least, there is a difference between Islamic legal proceedings and many Western ones. The judge's primary purpose is to be some sort of mediator between the parties. Compromise is much preferred over head-to-head conflicts. The first objective is to come to an agreement which makes sure that both parties can resume their relationship. Starting official proceedings is regarded as an ultimum remedium ${ }^{59}$.

\section{CONFUCIANISM}

Opinions are divided on whether Confucianism is a religion or not. There is, however, an increasing tendency to classify it as a religion both in the

${ }_{54}$ Awad and Michael, supra note 48 at p. 988; Kilborn, supra note 48 at p. 17.

${ }_{55}$ McMillen, supra note 48 at p. 4. For a different opinion, see N. Zada, A. Lahsasna, M. Yusuf Saleem, Towards a Corporate Model of Islamic Law of Insolvency: A Note on "Voluntary Insolvency", “ISRA International Journal of Islamic Finance” 2015, vol. 7, p. 141.

${ }_{56}$ Awad and Michael, supra note 48 at p. 989-990; McMillen, supra note 48 at p. 5.

57 McMillen, supra note 48.

${ }_{58}$ Awad and Michael, supra note 48 at p. 989; McMillen, supra note 48 at p. 5.

${ }^{59}$ Kilborn, supra note 48 at p. 27-28. 
West and the East ${ }^{60}$. For present purposes, Confucianism is considered to be a religion. Confucianism does not contain rules regarding insolvency in the same way as Islamic law. It rather encompasses principles which have an influence on how people tend to look at insolvency and use insolvency proceedings. Some of these influences will be shown next.

Confucianism knows a difference between $l i$ and $f a$. $L i$ entails a body of moral rules, whereas $f a$ consists of rules which are enforced by means of punishment ${ }^{61}$. The Legalist tradition of law regarded $f a$ as the principal way of structuring society ${ }^{62}$. Confucius, on the other hand, thought it better for people to follow rules because they are morally obliged to do so, and not because they want to avoid punishment. Fa could also lead to people trying to evade the law ${ }^{63}$. Because of the moral force of $l i$ and the punishing nature of $f a, l i$ can be seen as enforcement before wrongdoing happens, and $f a$ as enforcement after the wrongdoing ${ }^{64}$. An important aspect of the Confucian emphasis on $l i$ is the desire to retain harmony. Litigation is seen as a bad thing, as an ultimum remedium. Because of the force of $l i$, not paying debts is viewed as a bad thing and if a case like this were to happen, the first course of action would be to try to find the middle way, to mediate ${ }^{65}$.

Legal innovation has been difficult in the past in China, because of its Confucian background. As people are more focused on $l i$ than on $f a$, changing a codified law does not mean people's conduct will change as well. And because Confucian ideas are not codified, but moral rules, one cannot change $l i$ by changing or adopting codified law ${ }^{66}$. According to Confucius, if there is a conflict between $l i$ and $f a, l i$ should prevail ${ }^{67}$.

${ }^{60} \mathrm{X}$. Yao, An Introduction to Confucianism, Cambridge: Cambridge University Press, 2000, p. 38-47.

${ }^{61}$ L. Lee and W. Lai, The Chinese Conceptions of Law: Confucian, Legalist, and Buddhist, 1978, 29 [in:] The Hastings Law Journal 1307, p. 1308-1309; R. Tomasic and P. Little, Insolvency Law \& Practice in Asia, Hong Kong: FT Law \& Tax Asia Pacific, 1997, p. 22.

62 The Legalist tradition was an opponent of the Confucian tradition, see Tomasic and Little, supra note 61 at p. 67.

\footnotetext{
${ }^{63}$ Ibid. at p. 22.

${ }^{64}$ Lee and Lai, supra note 61 at p. 1308-1309.

65 Tomasic and Little, supra note 61 at p. 22-23.

${ }^{66} \mathrm{Ibid}$. at p. 23-24.

${ }^{67}$ Lee and Lai, supra note 61 at p. 1310.
} 
Research performed in the late 1990s showed that the Confucian background of Chinese people still had an influence on how they saw and used insolvency proceedings. There was quite some stigma attached to insolvency because it disrupts harmony ${ }^{68}$. The same was true for Taiwan ${ }^{69}$. An interviewee stated that because of this Confucian influence, there were many unofficial insolvency proceedings ${ }^{70}$. There was also a big stigma in Indonesia, but it is unclear whether this was due to Confucian influences ${ }^{71}$.

\section{IMPACT ON TRANSPLANTS}

What do these religious backgrounds mean for the success of corporate rescue transplants? There is no need for the transplant to be exactly in conformity with the existing religious background in the adopting country. This would dramatically decrease the amount of possible transplants. On the other hand, it is important to remember that the interpretation by the interpreter of the transplanted law will be influenced by his cultural and religious background, that it is easier to adopt a transplant which is close to the cultural and religious background of the adopting country, and that there is a chance of rejection if the cultural and religious background of the adopting country is not the same as the one in the transplant's origin country.

Looking at Islamic law, shari' ah principles are focused on liquidation. Reorganization is not forbidden expressis verbis, but because Islamic law is opposed to final discharge for other reasons than death or creditor kindness, reorganization could be a difficult institution to transplant to Islamic countries. What would be especially hard to approve on the basis of shari' ah principles with regard to reorganization, is the so-called cram down power, which entails that, if some creditors have voted against a reorganization plan, they can still be bound by it because either enough other creditors in their class have voted in favour (regular cram

\footnotetext{
${ }_{68}$ Tomasic and Little, supra note 61 at p. 48-49.

${ }^{69}$ Ibid. at p. 48.

${ }^{70}$ Ibid. at p. $48-49$.

${ }^{71}$ Ibid. at p. 222; R. Tomasic and others, Insolvency Law Administration and Culture in Six Asian Legal Systems, 2009, p. 22, available at https:// papers.ssrn.com/sol3/papers. cfm?abstract_id=1446648 [last accessed 21.4.2018].
} 
down) or because the court has approved the plan notwithstanding the disapproval of some classes of creditors (cross-class cram down) ${ }^{72}$. It is also normal to appoint an insolvency receiver to liquidate the assets. After the declaration of insolvency, the debtor falls into the same category as minors, the insane, and the incapacitated. These two things may make it hard to transfer the debtor in possession system, which entails that the debtor retains control over his assets during reorganization proceedings ${ }^{73}$.

The stigma which may play a role as a result of Confucian thinking may have the consequence that directors of companies are not very inclined to file a petition for reorganization proceedings, as this constitutes an acknowledgment of failure. On the other hand, reorganization may be viewed as less problematic than liquidation, because normally in liquidation the amount of debt repaid is lower than in reorganization. If the transplant were to enable informal proceedings, this could perhaps increase the chance of its success, for this has already happened in Taiwan and is more consistent with Confucian teachings. Trying to save the company enables the directors to prevent loss of face. But if the reorganization procedure is not used, the Confucian background may be an explanation.

Because of the importance of $l i$ compared to $f a$ in Confucian thought, one should consider the possibility that the transplant will not be used as extensively as hoped, especially if the transplant is not in accordance with $l i$, for in such a situation $l i$ will prevail.

All these examples point in the direction of a required awareness and appreciation for the religious background of adopting countries. This does not mean that transplants will fail if they are not exactly in line with this background. As emphasized above by the words could and may, there is no guarantee that the background described will have an effect on the acceptance of the rescue model. It is however suggested that it is easier for the transplant to be accepted and used if it considers these cultural aspects ${ }^{74}$. As a consequence, it is better if, for every developing

${ }^{72}$ See e.g. 11 US Code $\$ 1126(c)$ for regular cram down and 11 US Code $\$ 1129(b)$ for cross-class cram down.

${ }^{73}$ See e.g. 11 US Code $\$ 1107$ and 11 US Code $\S 1108$.

${ }^{74}$ Tomasic and others, supra note 71 at p. 31. 
country, there is a different rescue model, which considers the specific characteristics of the adopting country.

\section{CONCLUSION}

What has been shown above does not lead to the conclusion that there is no single model of corporate rescue regime which is suitable for adoption in all developing countries. Some conclusions can however be drawn: no adopted law will be used in the same way as the original transplant; it is hard for the transplant to have success if it has a relation with the culture of the country of origin which is not present in the adopting country; religion as part of culture can have an influence on whether, and the way in which, the adopted law is used; and a transplant which considers the adopting country's cultural background will have a greater chance of success. So even though it may be possible to adopt a single corporate rescue regime model in all developing countries, the chance of successful adoption is higher if the transplant is attuned to the cultural background of every individual developing country. This leads to the advice to adapt the transplant to the specific cultural backgrounds of the adopting developing country. 